\title{
Analisis Model Komunikasi Dalam Foto Jurnalistik
}

\author{
Derli Omega Sombu, Eko Harry Susanto \\ derli.sombu589@gmail.com,ekos@fikom.untar.ac.id
}

Fakultas Ilmu Komunikasi Universitas Tarumanagara, Jakarta

\begin{abstract}
Today's technological developments make access to information quicker and faster, with no space and time constraints. Mass Media is one of the channels for most people to know the latest information. Each media has a different model of communication and a separate way of delivering information to attract audiences. The presence of photojournalism in the news becomes one of the fascinations for media audiences when reading news. The selection of phototypes and elements of supporting value in journalistic photographs can affect the reaction (feedback) and emotions of the reader. Tempo.co is one of the media that uses the work of photojournalism in the news to captivate its rise. The garbage Problema Bantargebang becomes a difficult thing to overcome. Functioning as a means of educating and providing information on the media community has its way of addressing this problem, one of which is Tempo.co. Communication is considered effective if there is feedback from the intent of the communicator. The purpose of this research is to analyze the communication model in photojournalism used by Tempo.co related to Bantargebang garbage edition Friday, April 5, 2019, and Friday 6 September 2019 against audience feedback. This research is a qualitative study that uses the foundation of phenomenology theory. Researchers want to understand the communication model used from the news of Bantargebang Garbage by Tempo.co for the audience, feedback arising from the preaching, and whether there is awareness from the audience to reduce the use of plastic as a form of Response to the news. After conducting various research and interviews, researchers get data and statements that are the answer to the problem. The results of this study were the differences in reactions arising from the different communication models used in photojournalism. Awareness in society to reduce the use of plastic waste.
\end{abstract}

Keyword: photographs of journalistic, communications model, feedback, tempo.co

\begin{abstract}
Abstrak
Perkembangan teknologi masa kini membuat akses terhadap informasi menjadi semakin cepat dan pesat, tanpa adanya batasan ruang dan waktu. Media massa menjadi salah satu saluran bagi orang kebanyakan untuk mengetahui informasi terkini. Setiap media memiliki model komunikasi yang berbeda-beda dan cara tersendiri dalam menyampaikan informasi agar dapat menarik perhatian khalayak. Kehadiran foto jurnalistik dalam berita menjadi salah daya pikat bagi khalayak media ketika membaca berita. Pemilihan jenis foto dan unsur pendukung nilai dalam foto jurnalistik dapat berpengaruh terhadap reaksi (umpan balik) dan emosional dari pembaca. Tempo.co merupakan salah satu media yang menggunakan karya foto jurnalistik dalam beritanya untuk memikat khalayaknya. Problema sampah Bantargebang menjadi hal sukar untuk diatasi. Berfungsi sebagai sarana dalam mengedukasi dan memberi informasi pada masyarakat media memiliki cara tersendiri dalam menyampaikan permasalahan ini, salah satunya Tempo.co. Suatu komunikasi dianggap efektif bila ada umpan balik yang sesuai dengan maksud komunikatornya. Tujuan dari penelitian ini ialah menganalisa model komunikasi dalam foto jurnalistik yang digunakan oleh Tempo.co terkait pemberitaan sampah Bantargebang edisi Jumat 5 April 2019 dan Jumat 6 September 2019 terhadap feedback khalayak. Penelitian ini merupakan penelitian kualitatif yang memakai landasan teori fenomenologi. Peneliti ingin memahami model komunikasi yang digunakan dari pemberitaan sampah Bantargebang oleh Tempo.co bagi khalayak, feedback yang timbul dari pemberitaan
\end{abstract}


itu, dan apakah ada kesadaran dari khalayak untuk mengurangi penggunaan plastik sebagai bentuk dari respon terhadap berita tersebut. Setelah melakukan berbagai penelitian dan wawancara, peneliti mendapatkan sebuah data dan pernyataan yang menjadi jawaban atas permasalahan yang ada. Hasil penelitian ini adalah adanya perbedaan reaksi yang timbul dari akibat perbedaan model komunikasi yang digunakan dalam foto jurnalistik. Adanya kesadaran dalam masyarakat untuk mengurangi penggunaan sampah plastik.

Kata Kunci: foto jurnalistik, model komunikasi, umpan balik, tempo.co

\section{Pendahuluan}

Kehidupan manusia tidak pernah luput dari komunikasi. Komunikasi sudah menjadi kebutuhan dasar bagi setiap orang untuk dapat bertukar pesan dan pikiran. "Komunikasi ialah peristiwa pengutaraan pesan dari komunikator pada komunikan peristiwa penyampaian pesan dari sumber (komunikator) kepada penerima (komunikan) melalui tahapan proses, media atau alat sehingga menyebabkan efek atau pengaruh." (Tatang, 2016).

Perkembangan teknologi masa kini membuat akses terhadap informasi menjadi semakin cepat dan pesat. Media massa menjadi salah satu saluran bagi orang kebanyakan untuk mengetahui informasi terkini. Pemakaian foto jurnalistik dalam pemberitaan, membuat berita menjadi lebih menarik untuk dibaca.

Sesuai dengan apa yang didefinisikan oleh Wijaya (2010) yang dimaksud "foto jurnalistik merupakan foto yang memiliki nilai berita atau foto yang atraktif bagi pembaca tertentu, dan informasi tersebut diberi kepada masyarakat sesingkat mungkin. Pengertian ini menandakan bahwa terdapat suatu pesan tertentu dalam foto tersebut sehingga layak diberitakan kepada masyarakat." (Gani, Rita dan Kusumalestari, Ratri Rizki, 2013).

Setiap berita membutuhkan foto dokumentasi sebagai bukti nyata dari peristiwa yang diberitakan. Penggunaan foto jurnalistik dalam berita dapat membantu pembaca atau masyarakat untuk turut merasakan kondisi yang terjadi dalam peristiwa tersebut, sehingga hal ini dapat menyentuh simpati dari pembaca untuk mengetahui proses terjadinya peristiwa tersebut. Foto jurnalistik sering digunakan oleh berbagai portal berita, baik cetak maupun online. Salah satunya Tempo.co.

Pada penelitian ini, peneliti meneliti tentang model komunikasi yang digunakan dalam foto jurnalistik yang ada pada Tempo.co seputar pemberitaan sampah Bantargebang edisi Jumat 5 April 2019 dan Jumat 6 September 2019. Pemberitaan sampah Bantargebang akhir-akhir ini cukup mendapat perhatian serius baik dari dalam negeri maupun mancanegara. Adanya ketertarikan akan foto jurnalistik yang digunakan dalam pemberitaan tersebut, alasan inilah yang membuat penulis ingin membuat penelitian yang berjudul "Analisis Model komunikasi dalam Foto Jurnalistik" yang digunakan oleh Tempo.co terhadap kasus sampah Bantargebang.

\section{Rumusan Masalah}

Berdasarkan latar belakang di atas, identifikasi masalah dalam penelitian ini adalah perbedaan reaksi yang timbul akibat disimilaritas model komunikasi yang digunakan dalam foto jurnalistik; dominansi model komunikasi dalam foto jurnalistik terkait pemberitaan sampah; kesadaran masyarakat dalam mengurangi penggunaan sampah plastik. Dengan demikian permasalahan yang akan dibahas adalah: 
Bagaimana model komunikasi dalam foto jurnalistik yang digunakan oleh Tempo.co terkait pemberitaan sampah Bantargebang edisi Jumat 5 April 2019 dan Jumat 6 September 2019 terhadap feedback khalayak?

\section{Tujuan Penelitian}

Berdasarkan rumusan masalah di atas, maka tujuan penelitian ini adalah

1. Penelitian ini bertujuan untuk mengetahui perbedaan reaksi yang timbul akibat disimilaritas model komunikasi yang digunakan dalam foto jurnalistik.

2. Penelitian ini bertujuan untuk mengetahui dominansi model komunikasi yang digunakan dalam foto jurnalistik terkait pemberitaan sampah.

3. Penelitian ini bertujuan untuk menganalisis kesadaran masyarakat dalam mengurangi penggunaan sampah plastik.

Peneliti berharap dengan adanya penelitian ini maka dapat memberikan manfaat untuk pihak-pihak yang membutuhkan. Adapun manfaat penelitian ini adalah:

\section{Manfaat Penelitian}

1. Manfaat Akademis : Penelitian diharapkan mampu memberikan pengetahuan dan pemahaman mengenai komunikasi antarbudaya khususnya mengenai pola komunikasi intrapersonal antarbudaya. Penelitian juga bermanfaat bagi pembaca untuk menambah wawasan ataupun sumber terhadap penelitian lainnya di masa yang akan datang.

2. Manfaat Praktis: Penelitian ini hendaknya dapat bermanfaat sebagai anjuran bagi para pembaca untuk mengetahui bagaimana model komunikasi dalam foto jurnalistik.

Teori yang dipakai dalam riset ini adalah model komunikasi yang dikemukakan oleh Cangara (2016) dalam bukunya pengantar ilmu komunikasi. Buku tersebut memperkenalkan tiga model komunikasi yaitu model analisis dasar komunikasi, model proses komunikasi, dan model komunikasi partisipasi. Selain itu penulis juga menggunakan teori jurnalistik karena penelitian ini berkaitan dengan pemberitaan di media. "Jurnalistik selalu dihubungkan dengan kegiatan pengumpulan, penulisan, penyuntingan dan penyampaian berita atau artikel opini dalam surat kabar atau majalah, siaran radio atau televisi terhadap khalayak". (Alo, 2011).

\section{Metode Penelitian}

Dalam penelitian ini, penulis menggunakan pendekatan penelitian kualitatif. "Menurut Strauss dan Corbin (1997), yang dimaksud dengan Penelitian kualitatif yakni jenis penelitian yang melahirkan penemuan-penemuan yang tidak bisa diperoleh dengan menerapkan prosedur-prosedur statistik atau cara-cara lain dari kuantifikasi" (Sujarweni, 2014).

Penelitian ini bersifat deskriptif, menurut (Sujarweni, 2014) penelitian deskriptif adalah penelitian yang dikerjakan untuk memahami nilai dari masingmasing variabel, baik satu variabel atau lebih, sifatnya independent tanpa membuat hubungan maupun perbandingan dengan variabel yang lain. Variabel tersebut dapat mendeskripsikan secara sistematik dan eksplisit perihal populasi atau mengenai bidang tertentu. 
Berdasarkan sejumlah pengertian yang tertera di atas, penulis menggunakan jenis penelitian deskriptif dalam penelitian ini karena penulis memandang bahwa permasalahan yang akan diteliti dapat mendeskripsikan, menjelaskan dan menggambarkan model komunikasi dalam foto jurnalistik yang digunakan oleh Tempo.co terkait pemberitaan sampah Bantargebang edisi Jumat 5 April 2019 dan Jumat 6 September 2019 terhadap feedback khalayak.

Husserl mendefinisikan fenomenologi sebagai pengalaman subjektif, suatu ilmu mengenai pemahaman dari pandangan pokok dari seseorang. Istilah "fenomenologi" sering dipakai sebagai opini umum untuk menunjukkan pada pengalaman subjektif atas beragam jenis dan tipe subjek yang ditemui. Istilah ini mengacu pada penelitian terdisiplin tentang kognisi dari perspektif pertama seseorang (Moleong, 2012).

Dalam penelitian ini penulis memakai landasan teori fenomenologi karena memungkinkan peneliti untuk berusaha memahami arti dari peristiwa dan kaitankaitannya dengan orang-orang yang berada dalam situasi tersebut, maksudnya disini peneliti ingin memahami arti model komunikasi yang digunakan dari pemberitaan terkait sampah Bantargebang oleh Tempo.co bagi khalayak dan feedback apa yang timbul dari pemberitaan tersebut.

\section{Teknik Pengolahan dan Analisis Data}

Menurut (Emzir, 2012) Analisis data adalah proses sistematis pencarian dan penataan transkrip wawancara, catatan lapangan, dan materi-materi lain yang telah dikumpulkan untuk meningkatkan pemahaman anda sendiri mengenai materi-materi tersebut dan memungkinkan anda memaparkan apa yang telah anda temukan pada orang lain.

Model Analisis data penelitian kualitatif berdasarkan pendapat Miles dan Huberman (1992), dilakukan melalui proses sebagai berikut: 1). Reduksi data sebagai proses penetapan, pemusatan perhatian pada penyederhanaan, pengikhtisaran dan transformasi data kasar yang timbul dari catatan-catatan di lapangan. 2). Penyajian data sebagai kumpulan informasi tersusun yang memberi kemungkinan adanya penarikan kesimpulan dan pengambilan tindakan. Penciptaan dan penggunaan penyajian data tidaklah terpisah dari analisis. 3). Menarik kesimpulan / verifikasi adalah kegiatan analisis yang ketiga, dari awal pengumpulan data seorang penganalisis kualitatif mulai mencari arti benda-benda, mencatat keteraturan, pola-pola, penjelasan, konfigurasi alur sebab akibat dan proposisi. (Susanto, 2018).

\section{Hasil Penemuan dan Diskusi}

Setelah melakukan penelitian dan wawancara mendalam dengan beberapa narasumber yang dipilih, penulis mendapatkan data dan pernyataan yang menjawab setiap rumusan masalah diatas. Menurut hasil wawancara dan riset, hal pertama yang didapatkan adalah adanya perbedaan reaksi yang muncul akibat dari perbedaan model komunikasi yang digunakan dalam foto jurnalistik. Penulis menemukan bahwa tidak semua media memberikan ruang bagi pembacanya untuk mengaspirasikan pendapatnya terhadap pemberitaan tersebut. Tetapi berbeda dengan Tempo.co.

Media yang satu ini membuka ruang bagi setiap khalayak untuk menyampaikan pendapatnya melalui kolom komentar yang ada. Akan tetapi reaksi dari khalayak Tempo kebanyakan didasari oleh minat dan pro kontra pembaca terhadap informasi yang disampaikan. Dalam kasus Bantargebang ini ada perbedaan 
minat informasi yang ingin diketahui khalayak, sehingga ada beberapa orang yang memberi respon terhadap berita tersebut dan ada juga yang tidak. Kedua, model komunikasi di Tempo.co ialah model komunikasi partisipasi. Komunikasi jenis ini bersifat dua arah.

Hal ini dibuktikan dengan tersedianya kolom komentar dalam setiap artikelnya. Ketiga, bersumber pada hasil wawancara, peneliti menemukan bahwa adanya kesadaran yang muncul pada masyarakat, salah satunya pembaca Tempo.co. Namun saat melakukan penelitian di lapangan peneliti menemukan adanya kesamaan pendapat dari Nufus, Subekti dan Ijar Karim selaku Karyawan Tempo bahwa foto yang digunakan dalam kedua artikel ini kurang efektif atau sesuai. Hal ini bisa dilihat dari ketidaksesuaian penggunaan foto utama dengan judul yang digunakan.

Pada foto edisi 6 November 2019 tidak ditemukan keselarasan antara judul dan foto begitu pula dengan edisi 5 April 2019, judul berita menceritakan keresahan warga karena uang belum cair namun pada foto, warga terlihat biasa-biasa saja makan diatas tumpukan sampah. Selain itu untuk jenis foto jurnalistik yang digunakan dalam artikel ini adalah berita umum, di mana foto peristiwanya terjadwal, rutin, dan biasa. Foto ini dikategorikan sebagai foto terkait yang berkedudukan sama dengan tulisan. Terakhir, bentuk dari kesadaran masyarakat atau pembaca Tempo.co untuk mengurangi penggunaan sampah plastik, kebanyakan dimulai dengan upaya menggunakan tumbler, tidak memakai sedotan, membawa tote bag, dan membuang sampah pada tempatnya

\section{Simpulan}

Berdasarkan hasil penelitian yang sudah dikerjakan peneliti tentang analisis model komunikasi dalam foto jurnalistik, berikut kesimpulan yang dibuat oleh penulis:

1. Terdapat perbedaan reaksi yang muncul untuk setiap jenis pemberitaan. Tanggapan yang diberikan oleh narasumber biasa dipengaruhi oleh minat atau ketertarikan pembaca terhadap topik yang dibahas, selain itu juga bisa dipengarui oleh pro atau kontranya individu tersebut isi berita.

2. Tempo.co ialah salah satu dari berbagai media yang sudah memberikan ruang bagi setiap pembacanya untuk menyampaikan aspirasi dan pendapatnya melalui kolom komentar. Model komunikasi yang digunakan oleh Tempo.co ialah model komunikasi partisipasi atau dua arah. Dominansi model foto jurnalistik terkait pemberitaan sampah Bantargebang yakni bersifat informatif. Foto yang digunakan masuk dalam kategori foto terkait atau penguat berita.

3. Masyarakat mulai memiliki kesadaran untuk mengurangi penggunaan sampah plastik. Hasil wawancara menunjukkan adanya kesadaran dari masing-masing individu untuk mengurangi penggunaan sampah plastik dan membuang sampah pada tempatnya. Hasil penelitian menyatakan seluruh pembaca Tempo.co melakukan tindakan penghematan plastik dengan mulai membawa tas, tumbler dan tidak menggunakan sedotan plastik.

\section{Ucapan Terima Kasih}

Segala Puji dan Hormat penulis panjatkan kepada Tuhan Yesus Kristus atas anugerah dan penyertaan-Nya sehingga penulis sanggup melaksanakan penelitian dan menyelesaikan penulisan jurnal ini. 
Penulis menyadari bahwa tanpa adanya dukungan doa dan masukan dari berbagai rekan pada penulis yang menjadi kekuatan dan motivasi bagi penulis untuk menuntaskan jurnal ini. Oleh karena itu, penulis ingin mengucapkan terima kasih yang sebesar-besarnya kepada semua pihak yang telah membantu dan mendukung. Peneliti berharap bahwa jurnal ini dapat menambah wawasan dan berguna bagi berbagai pihak. Akhir kata penulis ucapkan sekian dan terima kasih.

\section{Daftar Pustaka}

Alo liliweri. (2011). Komunikasi Serba Ada Serba Makna. Jakarta: Prenada Media Group.

Cangara, Hafied (2016). Pengantar Ilmu Komunikasi. Jakarta: RajaGrafindo Persada. Emzir. (2012). Metodologi Penelitian Kualitatif: Analisis Data. Jakarta: Rajawali Pers Gani, Rita., \& Kusumalestari, Ratri Rizki. (2013). Foto Jurnalistik Suatu Pengantar. Bandung: Simbiosa Rekatama Media.

Moleong, Lexy J. (2012). Metodologi Penelitian Kualitatif. Bandung: Remaja Rosdakarya.

Sujarweni, V. Wiratna. (2014). Metode Penelitian: Lengkap, Praktis, dan Mudah Dipahami. Yogyakarta: Pustaka Baru Press.

Susanto, Eko Harry. (2018). Komunikasi Manusia: Teori dan Praktik Dalam Penyampaian Gagasan. Jakarta: Mitra Wacana Media

Tatang. (2016). Dinamika Komunikasi. Bandung: Pustaka Setia 